\title{
Analisis Kemampuan Berpikir Logis Matematis Siswa SMP Kelas VII dalam Memecahkan Masalah Matematika Ditinjau dari Gaya Belajar
}

\author{
Desi Melatul Fitriyah, Nonik Indrawatiningsih, Miftahul Khoiri
}

(C) 2019 JEMS (Jurnal Edukasi Matematika dan Sains)

This is an open access article under the CC-BY-SA license (https://creativecommons.org/licenses/bysa/4.0/) ISSN 2337-9049 (print), ISSN 2502-4671 (online)

\begin{abstract}
Abstrak:
Kemampuan berpikir logis memiliki peran penting dalam pemecahan dan pembelajaran konsep matematika dan untuk meningkatkan hasil belajar. Penelitian ini adalah penelitian kualitatif deskriptif yang bertujuan untuk mendeskripsikan kemampuan berpikir logis siswa kelas VII dalam memecahkan masalah matematika yang ditinjau dari gaya belajar pada pokok bahasan aritmatika sosial. Subjek dalam penelitian ini berjumlah 3 siswa dengan siswa bergaya belajar visual, auditori dan kenestetik. Pengumpulan data menggunakan angket gaya belajar, tes kemampuan berpikir logis, wawancara dan dokumentasi. Berdasarkan hasil penelitian, subjek bergaya belajar visual memiliki kemampuan berpikir logis yaitu pada tahap klasifikasi, tahap menghubungkan, tahap menghitung dan tahap menarik kesimpulan. Subjek bergaya belajar auditori memiliki kemampuan berpikir logis yaitu pada tahap klasifikasi, tahap menghubungkan, tahap menghitung dan tahap menarik kesimpulan. Sedangkan subjek bergaya belajar kinestetik memiliki kemampuan berpikir logis yaitu pada tahap klasifikasi, tahap menghubungkan dan tahap menarik kesimpulan.
\end{abstract}

Kata Kunci : Berpikir Logis; Pemecahan Masalah; Gaya Belajar

\begin{abstract}
:
The ability to think logically has a vital role in solving and learning mathematical concepts, its to improve learning outcomes. This research is descriptive qualitative research that aims to describe the ability of students to think logically in class VII in solving mathematical problems in terms of learning styles on the subject of social arithmetic. The subjects in this study amounted to 3 students with students learning styles visual, auditory, and kinesthetic. Data collection uses learning style questionnaires, logical thinking skills tests, interviews, and documentation. The results of the study show that three stages of the logical thinking ability with visual learning style subject, namely the connecting stage, the counting stage, and the conclusion drawing stage. Auditory learning style subjects can think logically that is at the classification stage, the connecting stage, the counting stage, and the conclusion drawing stage. Whereas the kinesthetic learning style subject can think logically, that is at the classification stage, the connecting stage, and the conclusion drawing stage.
\end{abstract}

Keywords : Logical Thinking; Problem Solving; Learning Style

\section{Pendahuluan}

Salah satu kemampuan yang erat kaitannya dengan pemecahan masalah matematika adalah kemampuan berpikir logis (penalaran logis) yaitu kemampuan menyimpulkan suatu kebenaran berdasarkan aturan, pola atau logika tertentu (Usdiyana dkk, 2009). Kemampuan berpikir logis perlu dikembangkan dalam pembelajaran matematika siswa, karena dapat meningkatkan kemajuan pemahaman matematika (Sumarmo, 2009). Kemampuan berpikir logis

Desi Melatul Fitriyah, STKIP PGRI Pasuruan

Desimela7284@gmail.com

Nonik Indrawatiningsih, STKIP PGRI Pasuruan

nonikphy.d@gmail.com

Miftahul Khoiri, STKIP PGRI Pasuruan

miftah.mipa@gmail.com 
memiliki peran penting dalam pemecahan dan pembelajaran konsep matematika dan untuk meningkatkan hasil belajar (Suragih, 2016).

Kemampuan berpikir seseorang dapat diukur dengan indikator berpikir logis. Menurut Sumarmo (2012) "kemampuan berpikir logis meliputi kemampuan: (1) menarik kesimpulan atau membuat, penarikan dan interprestasi berdasarkan proporsi yang sesuai, (2) menarik kesimpulan atau membuat perkiraan dan prediksi berdasarkan peluang, (3) menarik kesimpulan atau membuat perkiraan atau prediksi berdasarkan korelasi antara dua variabel, (4) menetapkan kombinasi beberapa variabel, (5) analogi adalah menarik kesimpulan berdasarkan keserupaan dua proses, (6) melakukan pembuktian, (7) menyusun analisa dan sintesa beberapa kasus". Hidayat (2014) mengatakan "ketujuh indikator tersebut dapat disederhanakan menjadi : (1) menarik kesimpulan analogi, generalisasi, dan menyususn konjektur, (2) menarik kesimpulan logis berdasarkan aturan inferensi, memeriksa validitas argumen, dan menyusun argumen yang valid, (3) menyusun pembuktian langsung, tak langsung, dan dengan induksi mtematika".

Jody \& Johnsoh (dalam Setiadi, 2017) memiliki pendapat lain tentang tentang berpikir logis. Ia mengatakan bahwa berpikir logis memiliki empat karakteristik yaitu (1) klasifikasi yaitu kemampuan siswa untuk menyebutkan semua informasi yang diketahui dan dan seluruh informasi yang ditanyakan. (2) menghubungkan yaitu kemampuan siswa untuk menghubungkan antara data yang diketahui dengan pengetahuan yang dimiliki sehingga mampu menyusun rencana penyelesaian dengan tepat. (3) menghitung yaitu kemampuan siswa melakukan operasi hitung matematika dengan tepat sehingga mendapatkan hasil jawaban yang benar. (4) menarik kesimpulan yaitu kemampuan menarik kesimpulan dari awal sampai akhir penyelesaian.

Berpikir logis seringkali dikaitkan dengan pemecahan masalah. Andriawan (2014:43) mengatakan bahwa pemecahan masalah adalah suatu ide atau pemikiran yang terarah secara langsung untuk menemukan solusi untuk suatu masalah. Guru dapat membantu siswa dalam memaksimalkan kemampuan pemecahan masalah siswa untuk mengkonstruksi pengetahuan mereka agar pengaruhnya terdapat kemampuan berpikir logis, analisis, dan kemampuan dalam memecahkan masalah matematika maupun masalah sehari-hari. Tarhadi (2007:102) menyatakan bahwa pengembangan dalam penalaran matematika akan mengembangkan pula kebiasaan berpikir logis dan juga dapat ditransfer ke ilmu-ilmu lain.

Penelitian terdahulu terkait kemampuan berpikir logis siswa dilakukan oleh oleh Rahmawati dan Kurniasari (2016:207) menunjukkan bahwa siswa yang memiliki kemampuan tinggi, sedang dan rendah memiliki kemampuan yang berbeda dalam berpikir, berargumen dan memberikan kesimpulan. Hasil penelitian yang dilakukan Andriawan dan Budiarto (2014) tentang kemampuan berpikir logis dalam pemecahan masalah matematika menunjukkan bahwa siswa yang berkemampuan matematika tinggi memiliki kemampuan berpikir logis yang tinggi, sedangkan siswa yang berkemampuan matematika sedang dan rendah memiliki kemampuan berpikir logis yang sedang dan rendah. Sehingga dapat dikatakan bahwa kemampuan berpikir logis siswa berbanding lurus dengan kemampuan matematika siswa.

Berdasarkan pemaparan diatas dapat disimpulkan bahwa dengan kemampuan berpikir logis siswa lebih mudah memahami konsep matematika dan secara tidak langsung dapat digunakan untuk memecahkan masalah matematika. Berdasarkan uraian diatas, peneliti tertarik untuk melakukan penelitian dengan judul “Analisis Kemampuan Berpikir Logis Siswa Dalam Memecahkan Masalah Matematika Ditinjau Dari Gaya Belajar". 


\section{Metode}

Jenis penelitian ini adalah jenis penelitian kualitatif deskriptif dengan pendekatan kualitatif. Dimana penelitian ini menganalisis hasil pekerjaan siswa berdasarkan tes kemampuan berpikir logis siswa yang ditinjau dari gaya belajar pada pokok bahasan aritmatika sosial. Penelitian ini dilaksanakan mulai tanggal 08 sampai 30 Mei 2018, dengan subjek penelitian siswa kelas VII F di SMP Negeri salah satu sekolah di Kabupaten Pasuruan. Peneliti mengambil 3 subjek yang memenuhi indikator gaya belajar yaitu 1 subjek bergaya belajar visual, 1 subjek bergaya belajar auditori dan 1 subjek bergaya belajar kinestetik. Teknik pengumpulan data pada penelitian ini adalah angket gaya belajar, tes kemampuan berpikir logis, wawancara dan dokumentasi. Analisis data yang digunakan dalam penelitian ini yaitu reduksi data, penyajian data penarikan kesimpulan.

\section{Hasil dan Pembahasan}

Pengambilan data dalam penelitian ini dilakukan pada beberapa siswa kelas VII di SMP Negeri salah satu sekolah di Kabupaten Pasurusan berdasarkan gaya belajar siswa dengan memberikan kuesioner/angket gaya belajar. Berikut ini akan dideskripsikan data hasil penelitian dari subjek yang terpilih, yaitu subjek bergaya belajar visual, subjek bergaya belajar auditori dan subjek bergaya belajar kinestetik. Selanjutnya data hasil penelitian akan diuraikan berdasarkan tahapan pemecahan masalah menurut polya serta komponen utama kemampuan berpikir logis yaitu meliputi klasifikasi, menghubungkan, menghitung dan menarik kesimpulan. Adapun hasil pengerjaan tes kemampuan berpikir logis siswa dan hasil wawancara dipaparkan sebagai berikut:

\section{Hasil analisis kuesioner/angket gaya belajar siswa}

Berdasarkan hasil kuesioner/angket gaya belajar visual, auditori dan kinestetik terdapat 45,45\% siswa bergaya belajar visual atau berjumlah 15 siswa, 30,30\% siswa bergaya belajar auditori atau berjumlah 10 siswa, 12,12\% siswa bergaya belajar kinestetik atau berjumlah 4 dan $12,12 \%$ siswa tidak mengikuti kuesioner gaya belajar atau berjumlah 4 siswa. Berdasarkan hasil kuesioner tersebut peneliti memperoleh 1 subjek bergaya belajar visual yaitu IPH, 1 subjek bergaya belajar auditori yaitu ZA dan 1 subjek bergaya belajar kinestetik yaitu MSAF.

\section{Hasil analisis tes kemampuan berpikir logis dan wawancara}

\section{a. Subjek dengan gaya belajar visual (IPH)}

Hasil pekerjaan subjek IPH pada soal nomor 1 yang digunakan untuk mengukur kemampuan berpikir logis dapat dilihat pada tabel dibawah ini:

Tabel 1. Hasil tes subjek IPH nomor 1

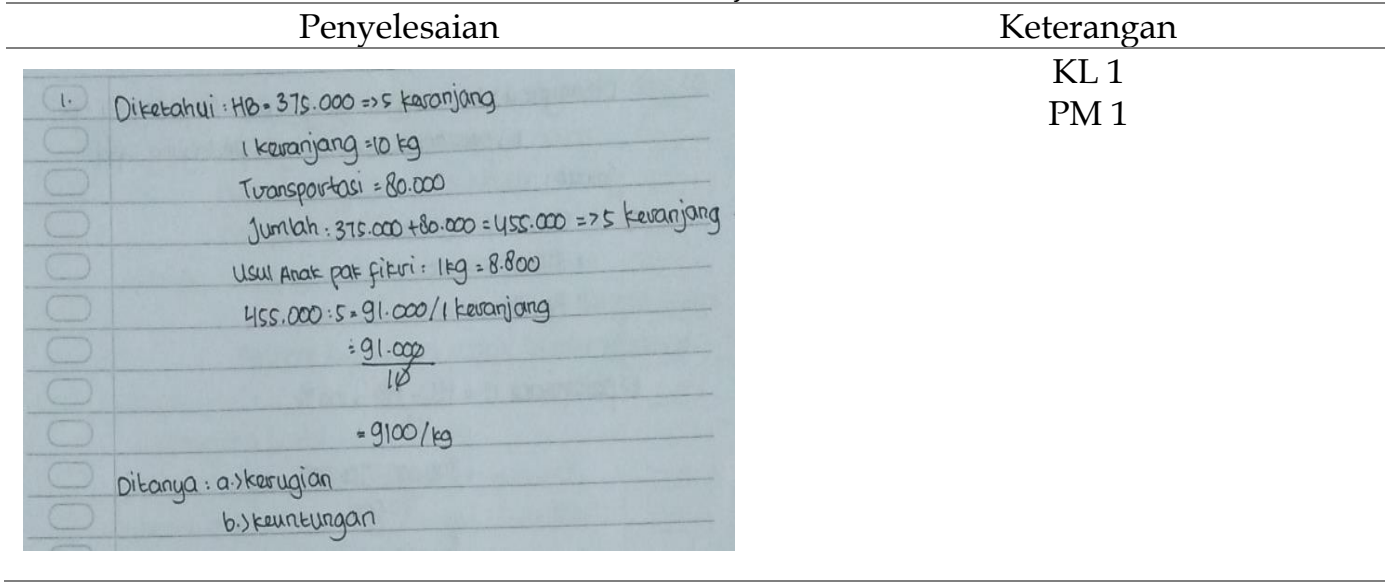




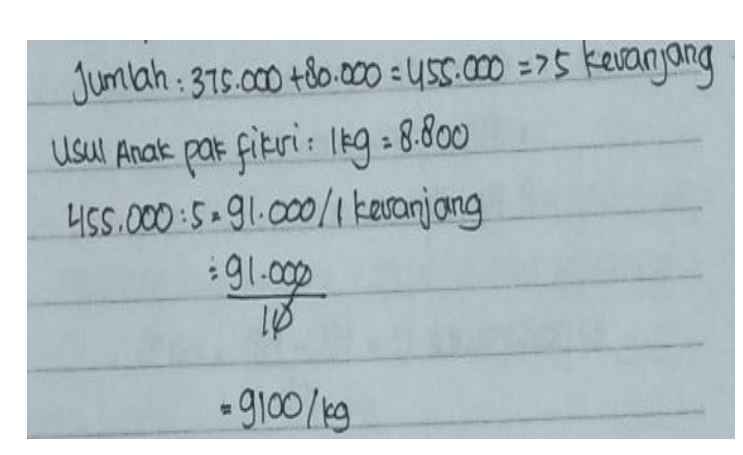

KL 2

PM 2

PM 3

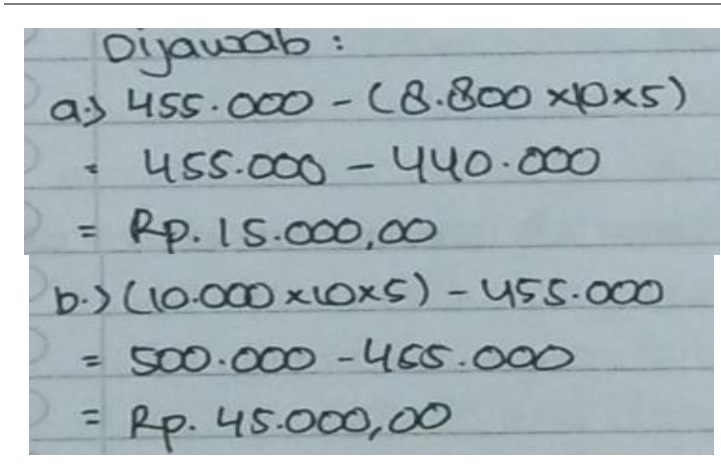

KL 3

PM 3

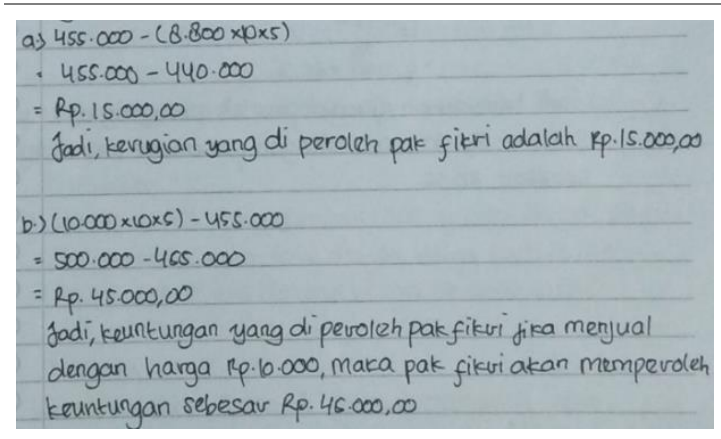

KL 4

PM 4

Dari hasil pekerjaan subjek IPH diatas, dapat dijelaskan bahwa:

1) KL 1: Klasifikasi

Subjek IPH dapat menuliskan informasi yang diketahui dari soal dengan tepat dan jelas dengan bahasa sendiri dan subjek IPH dapat merumuskan pertanyaan yang diminta dari soal dengan menggunakan bahasa sendiri. Sehingga subjek IPH dapat melalui tahap klasifikasi dimana subjek IPH dapat menyatakan masalah yang ditunjukkan dengan dapat menentukan informasi yang diketahui dalam soal secara tepat dan jelas dengan bahasa sendiri atau mengubah dalam bentuk kalimat matematika (model matematika) dan dapat menganalisis pengertian dari masalah yang ditunjukkan dengan dapat merumuskan pertanyaan yang diminta dari soal dengan bahasa sendiri atau mengubah dalam kalimat matematika (model matematika). Berdasarkan hasil tes kemampuan berpikir logis subjek IPH dapat memahami masalah terbukti bahwa subjek IPH dapat menuliskan semua informasi yang diketahui dan merumuskan 
pertanyaan yang diminta soal nomor 1. Adapun kutipan wawancara peneliti dengan subjek IPH adalah sebagai berikut:

P1 : Informasi apa yang ada dalam soal nomor 1 ?

J1 : Yang diketahui harga 5 keranjang mangga sama dengan Rp.375.000,00, 1 keranjang berisi $10 \mathrm{~kg}$ mangga, biaya transportasi sama dengan Rp. 80.000,00, jumlah biaya (total harga beli) sama dengan Rp. 455.000,00, harga $1 \mathrm{~kg}$ mangga sama dengan Rp. 8.800,00.

P2 : Apa yang ditanyakan soal tersebut?

J2 : Pada soal nomor 1a berapa kerugian yang dialami Pak Fikri dan soal $1 b$ berapa keuntungan yang diperoleh Pak Fikri.

Berdasarkan hasil wawancara diatas dapat diketahui bahwa subjek IPH telah melalui tahap klasifikasi dengan baik dan telah memahami masalah pada soal nomor 1. Subjek IPH dapat menyebutkan semua informasi yang diketahui dan dapat merumuskan pertanyaan yang diminta dari soal nomor 1 dengan lengkap dan benar.

Berdasarkan hasil tes tulis dan hasil wawancara, subjek IPH telah memahami masalah pada soal nomor 1. Subjek IPH dapat menuliskan semua informasi apa saja yang diketahui dari soal nomor 1 dengan benar dan jelas dengan bahasa sendiri. Subjek IPH juga dapat merumuskan pertanyaan dari soal nomor 1 dengan benar. Setelah dikonfirmasi melalui tahap wawancara ternyata didapat fakta bahwa subjek IPH memang benar dapat menyebutkan semua informasi yang diketahui dengan benar dan merumuskan pertanyaan dari soal nomor 1 dengan tepat dengan bahasa sendiri. Sehingga dapat dikatakan bahwa subjek IPH telah melalui tahap klasifikasi dengan baik.

2) KL 2: Kemampuan Menghubungkan

Dari penyelesaian yang dilakukan dimana subjek IPH menuliskan semua informasi yang diketahui kemudian menghubungkan antara data yang diketahui dari soal dengan pengetahuan matematika yang dimiliki mengubah dalam bentuk kalimat matematika (model matematika) secara jelas dan tepat dengan bahasa sendiri sehingga didapat suatu hasil yang kemudian digunakan untuk melakukan proses penyelesaian pada tahap berikutnya. Dapat dikatakan bahwa subjek IPH telah merencanakan penyelesaian dan melakukan rencana penyelesaian, dapat memberikan keterangan pada bentuk matematika dari apa yang diketahui sebelumnya dan dapat menentukan rumus yang akan digunakan dengan benar dan tepat. Subjek IPH juga mampu menyusun rencana penyelesaian dengan tepat. Adapun kutipan wawancara peneliti dengan subjek IPH adalah sebagai berikut:

P3 : Pengetahuan/konsep apa saja (yang sudah kamu pelajari) yang dibutuhkan untuk menyelesaikan masalah tersebut?

J3 : Mencari kerugian dan keuntungan dengan mengetahui harga beli dan harga jual.

P4 : Apa yang dimaksud dari informasi yang telah kamu ketahui tadi?

J4 : Karena yang diketahui harga beli 5 keranjang mangga sama dengan Rp. 375.000,00 dan biaya transportasi sama dengan Rp. 80.000,00 maka harga beli 5 keranjang ditambah biaya transportasi sama dengan Rp. 375.000,00 ditambah Rp. 80.000,00 sama dengan Rp. 455.000,00 adalah total harga beli. Harga jual adalah harga $50 \mathrm{~kg}$ mangga dikali Rp. 8.800,00 sama dengan Rp. 440.000,00.

P5 : Oke, apakah semua informasi (yang diketahui) kamu gunakan dalam menyelesaikan soal?

J5 : Iya.

Berdasarkan hasil wawancara diatas dapat diketahui bahwa subjek IPH telah melakukan tahap menghubungkan dengan baik. Subjek IPH mengemukakan apa yang dimaksud dari apa 
yang diketahui kemudian menghubungkannya dengan pengetahuan yang dimiliki dengan benar.

Berdasarkan hasil tes tulis dan hasil wawancara, subjek IPH dapat melakukan tahap menghubungkan dengan benar. Setelah dikonfirmasi melalui tahap wawancara ternyata didapat fakta bahwa subjek IPH memang benar dapat melakukan tahap menghubungkan dengan jelas dan benar dan menggunakan semua informasi yang diketahui pada soal dan dapat menjelaskan alasan mengapa menggunakan semua informasi tersebut, sehingga dapat dikatakan bahwa subjek IPH telah melalui tahap menghubungkan dengan baik.

3) KL 3: Tahap Menghitung

Pada tahap menghitung, dimana subjek IPH mampu melakukan operasi hitung dengan tepat dan mampu menyelesaikan dengan benar sesuai dengan langkah-langkah pada rencana penyelesaian. Adapun kutipan wawancara peneliti dengan subjek IPH adalah sebagai berikut:

P6 : Apakah rencana penyelesaian yang kamu pilih atau gunakan sudah runtut dan benar?

J6 : Iya.

P7 : Bagaimana cara kamu untuk bisa menjawab soal berdasarkan rencana penyelesaian yang kamu pilih?

J7 : Kalau yang 1a mencari kerugian dengan menemukan harga beli terlebih dahulu yaitu harga 5 keranjang mangga Rp. 375.000,00 ditambah biaya transportasi Rp. 80.000,00 sama dengan Rp. 455.000,00 itu adalah harga belinya, kemudian harga beli dikurangi dengan harga $1 \mathrm{~kg}$ mangga dikali $10 \mathrm{~kg}$ mangga dan hasilnya dikali 5 keranjang mangga sama dengan Rp. 440.000,00 jadi Rp. 455.000,00 dikurangi Rp. 440.000,00 sama dengan Rp. 15.000,00 adalah kerugian. Kalau yang $1 b$ harga per-kg Rp. 10.000,00 dikali $10 \mathrm{~kg}$ mangga dikali 5 keranjang mangga sama dengan Rp. 500.000,00 (harga jual) kemudian dikurangi dengan harga beli Rp. 455.000,00 sama dengan Rp. 45.000,00 adalah keuntungan.

Berdasarkan hasil wawancara diatas dapat diketahui bahwa subjek IPH telah melalui tahap menghitung dengan benar. Subjek IPH dapat menjelaskan langkah-langkah penyelesaian dengan runtut dan jelas dan menemukan hasil akhir penyelesaian yang benar.

Berdasarkan hasil tes tulis dan hasil wawancara, subjek IPH dapat melakukan tahap menghitung dengan benar sesuai langkah-langkah penyelesaian dan rencana penyelesaian. Setelah dikonfirmasi melalui tahap wawancara ternyata didapat fakta bahwa memang benar subjek IPH melakukan semua langkah-langkah dan rencana penyelsaian dengan baik sehingga didapat hasil penyelesaian yang benar. Sehingga dapat dikatakan bahwa subjek IPH telah melalui tahap menghubungkan dengan baik.

4) KL 4: Tahap Menarik Kesimpulan

Subjek IPH menarik kesimpulan dari awal sampai akhir penyelesaian dengan tepat dari sejumlah ide yang didapatnya dalam menyelesaikan soal. Adapun kutipan wawancara peneliti dengan subjek IPH adalah sebagai berikut:

P8 : Mengapa rencana penyelesaian tersebut kamu gunakan atau kamu lakukan?

J8 : Yaitu tadi kak, karena untuk mencari kerugian kita harus mencari harga beli dikurangi harga jual dan begitu sebaliknya untuk mencari keuntungan harus mencari harga jual dikurangi harga beli.

P9 : Dapatkah kamu memberikan kesimpulan dari soal nio.1 (tentukan kerugian dan keuntungan)?

J9 : Bisa. Kerugian yang dialami pak Fikri adalah sebesar Rp. 15.000,00. Dari kerugian yaitu harga beli dikurangi harga jual maka harga beli lebih besar (>) dari harga jual. Sedangkan kentungan yang diperoleh pak Fikri adalah sebesar Rp.45.000,00. Dari keuntungan yaitu harga jaul di kurangi harga beli maka harga beli lebih kecil (<) dari harga jual.

Berdasarkan hasil wawancara, dapat diketahui bahwa subjek IPH langsung membuat hasil akhir dari pekerjaannya dan menuliskannya dengan benar dan jelas. Berdasarkan hasil tes tulis 
dan hasil wawancara, subjek IPH dapat membuat kesimpulan dengan benar. Hal ini dapat dilihat dari pekerjaan subjek IPH yang menuliskan kesimpulan akhir dengan benar. Setelah dikonfirmasi melalui tahap wawancara ternyata didapat suatu fakta bahwa subjek IPH dapat membuat kesimpulan dari hasil akhirnya dengan benar. Sehingga dapat dikatakan bahwa subjek IPH telah melalui tahap menarik kesimpulan dengan baik.

b. Subjek dengan gaya belajar auditori (ZA)

Hasil pekerjaan subjek ZA pada soal nomor 1 yang digunakan untuk mengukur kemampuan berpikir logis dapat dilihat pada tabel dibawah ini:

Tabel 2. Hasil tes subjek ZA nomor 1

\begin{tabular}{cc}
\hline Penyelesaian & Keterangan \\
\hline $\begin{aligned} \text { 1. a. Diketahui : Harga } 5 \text { keranjang mangga }=375.000 \\
\text { - tiap keranjang berisi } 10 \mathrm{~kg} \\
\text { - Biaya transportasi : } 80.000\end{aligned}$ & KL 1 \\
- Harga $1 \mathrm{~kg}=8.800$ & \\
Ditanya: kerugian yg dialami pakfikvi
\end{tabular}

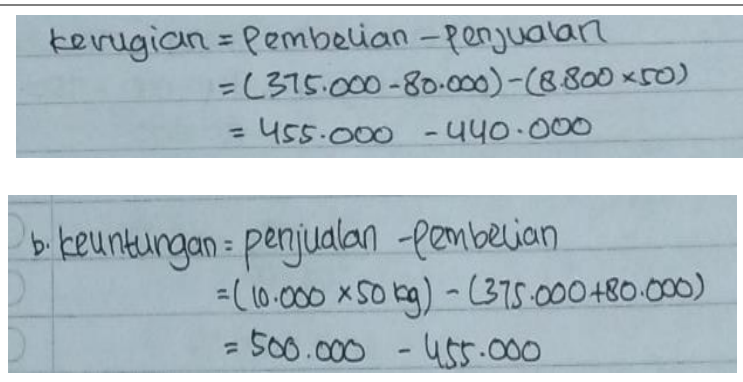

KL 2

PM 2

PM 3



KL 3

PM 3
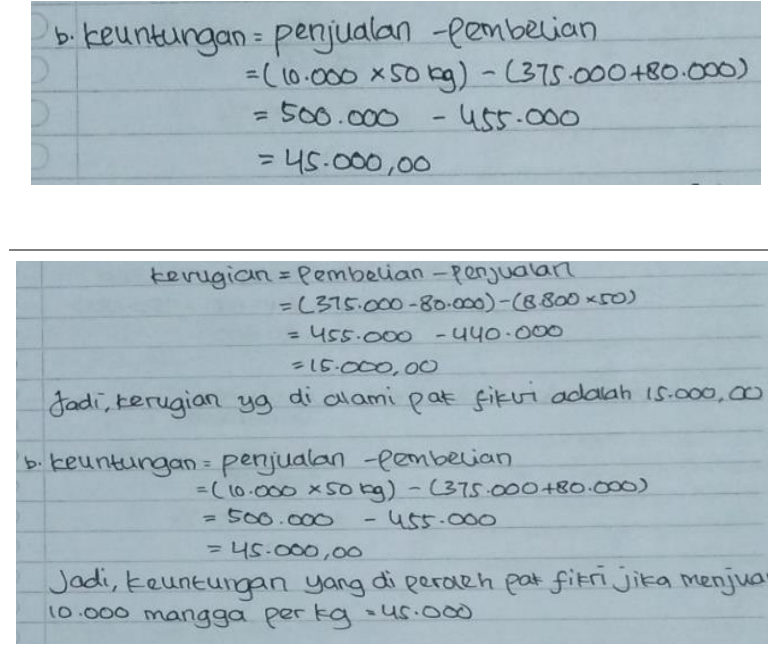

KL 4

PM 4 
Dari hasil pekerjaan subjek ZA diatas, dapat dijelaskan bahwa:

1) KL 1: Klasifikasi

Subjek ZA dapat menuliskan semua informasi yang diketahui dari soal dengan tepat dan jelas dengan bahasa sendiri. Subjek ZA juga dapat merumuskan pertanyaan yang diminta dari soal dengan bahasa sendiri, namun subjek ZA hanya merumuskan pertanyaan dari soal 1a saja. Adapun kutipan wawancara peneliti dengan subjek ZA adalah sebagai berikut:

P1 : Informasi apa yang ada dalam soal nomor 1 ?

J1 : Harga 5 keranjang mangga Rp. 375.000,000, setiap keranjang mangga berisi $10 \mathrm{~kg}$, biaya transportasi Rp. 80.000,00, harga $1 \mathrm{~kg}$ mangga Rp. 8.800,00.

P2 : Apa yang ditanyakan soal tersebut?

J2 : Yang 1a kerugian yang dialami Pak Fikri dan $1 b$ keuntungan yang diperoleh Pak Fikri.

P3 : Coba lihat kembali pekerjaanmu apakah semua yang ditanyakan dalam soal nomor dua sudah kamu tuliskan?

J3 : Ternyata yang $2 b$ belum saya tuliskan.

P4 : Kenapa tidak kamu tuliskan?

J4 : Lupa.

Berdasarkan hasil wawancara dapat diketahui bahwa subjek ZA telah melalui tahap klasifikasi dengan benar. Subjek ZA dapat menyebutkan semua informasi yang diketahui dan dapat merumuskan pertanyaan yang diminta dari soal nomor 1 dengan lengkap dan benar.

Berdasarkan hasil tes tulis dan hasil wawancara, subjek ZA sudah dapat menuliskan semua informasi apa saja yang diketahui dari soal nomor 1 dengan benar dan jelas dengan bahasa sendiri. Subjek ZA juga merumuskan pertanyaan dari soal nomor 1 tetapi hanya merumuskan soal nomor 1a saja. Setelah dikonfirmasi melalui tahap wawancara ternyata didapat fakta bahwa subjek ZA memang benar dapat menyebutkan semua informasi yang diketahui dan merumuskan pertanyaan dari soal nomor 1 dengan benar. Tetapi setelah dikonfirmasi lagi mengapa subjek ZA merumuskan pertanyaan hanya soal nomor 1a saja subjek ZA menjawab bahwa dia lupa merumuskan pertanyaan soal nomor 1 b. Sehingga dapat dikatakan bahwa subjek ZA tidak melalui tahap klasifikasi dengan baik.

2) KL 2: Tahap Menghubungkan

Dari penyelesaian yang dilakukan, dimana subjek ZA menuliskan semua informasi yang diketahui kemudian menghubungkan antara data yang diketahui dari soal dengan pengetahuan yang dimiliki. Subjek ZA menuliskannya langsung pada proses penyelesaian dalam bentuk kalimat matematika (model matematika) secara jelas dan tepat dengan bahasa sendiri. Subjek IPH telah merencanakan penyelesaian dan melakukan rencana penyelesaian, dapat memberikan keterangan pada bentuk matematika dari apa yang diketahui sebelumnya dan dapat menentukan rumus yang akan digunakan dengan benar dan tepat. Subjek ZA dapat menyusun rencana penyelesaian dengan tepat. Adapun kutipan wawancara peneliti dengan subjek ZA adalah sebagai berikut:

P5 : Pengetahuan/konsep apa saja (yang sudah kamu pelajari) yang dibutuhkan untuk menyelesaikan masalah tersebut?

J5 : Konsep mencari kerugian dan keuntungan dengan mencari harga beli dan harga jual.

P6 : : Apa yang dimaksud dari informasi yang telah kamu ketahui tadi?

J6 : Yang diketahui harga 5 keranjang mangga sama dengan Rp. 375.000,00, biaya transportasi Rp. 80.000,00 maka Rp. 375.000,00 ditambah RP. 80.000,00 sama dengan Rp. 455.000,00 adalah harga beli. . Harga jual adalah harga $50 \mathrm{~kg}$ mangga dikali Rp. 8.800,00 sama dengan Rp. 440.000,00. 
P7 : Apakah semua informnasi (yang diketahui) kamu gunakan dalam menyelesaikan soal?

J7 : Iya.

Berdasarkan hasil wawancara dapat diketahui bahwa subjek ZA telah melakukan tahap menghubungkan dengan baik. Subjek ZA mengemukakan apa yang dimaksud dari apa yang diketahui kemudian menghubungkan dengan pengetahuan yang dimiliki dengan benar.

Berdasarkan hasil tes tulis dan hasil wawancara, subjek ZA dapat melakukan tahap menghubungkan dengan benar. Setelah dikonfirmasi melalui tahap wawancara ternyata didapat fakta bahwa subjek ZA memang benar dapat melakukan tahap menghubungkan dengan jelas dan benar dan menggunakan semua informasi yang diketahui pada soal dalam menyelesaikan soal nomor 1. Sehingga dapat dikatakan bahwa subjek ZA telah melalui tahap menghubungkan dengan baik.

3) KL 3: Tahap Menghitung

Pada tahap menghitung, subjek ZA mampu melakukan operasi hitung pada penyelesaian soal nomor 1. Subjek ZA mampu menyelesaikan dengan benar sesuai dengan langkah-langkah pada rencana penyelesaian. Adapun kutipan wawancara peneliti dengan subjek ZA adalah sebagai berikut:

P8 : Apakah rencana penyelesaian yang kamu pilih atau gunakan sudah runtut dan benar?

J8 : Iya.

P9 : Bagaimana cara kamu untuk bisa menjawab soal berdasarkan rencana penyelesaian yang kamu pilih?

J9 : Kalau yang 1a mencari kerugian dengan mencari pembelian terlebih dahulu. Pembelian yaitu harga 5 keranjang mangga Rp. 375.000,00 ditambah biaya transformasi Rp. 80.000,00 sama dengan Rp. 455.000,00 adalah harga beli. Kemudian mencari penjualan yaitu harga $1 \mathrm{~kg}$ mangga Rp. 8.800,00 dikali $50 \mathrm{~kg}$ mangga sama dengan $\mathrm{Rp}$. 440.000,00 jadi kerugiannya adalah pembelian dikurangi penjualan sama dengan Rp. 455.000,00 dikurangi 440.000,00 sama dengan Rp. 15.000,00. Yang $1 b$ mencari keuntungan dengan mencari penjualan terlebih dahulu. Penjualan yaitu harga $1 \mathrm{~kg}$ mangga Rp. 10.000,00 dikali 50kg mangga sama dengan Rp. 500.000,00 adalah penjualan. Kemudian mencari pembelian yaitu harga 5 keranjang mangga Rp. 375.000,00 ditambah biaya transportasi $R p$. 80.000,00 sama dengan Rp.455.000,00 jadi keuntungan adalah penjulan dikurangi pembelian sama dengan Rp. 500.000,00 dikurangi Rp. 375.000,00 sama dengan Rp. 45.000,00.

Berdasarkan hasil wawancara dapat diketahui bahwa subjek ZA telah melalui tahap menghitung dengan benar pada soal nomor 1. Subjek ZA dapat menjelaskan langkah-langkah penyelesaian dengan runtut dan benar.

Berdasarkan hasil tes tulis dan hasil wawancara subjek ZA dapat melakukan tahap menghitung dengan benar sesuai langkah-langkah penyelesaian dan rencana penyelesaian. Setelah dikonfirmasi melalui tahap wawancar ternyata didapat fakta bahwa memang benar subjek ZA melakukan semua langkah-langkah dan rencana penyelesaian dengan baik dan baik sehingga didapat hasil penyelesaian yang benar. Sehingga dapat dikatakan bahwa subjek ZA talah melalui tahap menghitung dengan baik.

4) KL 4 : Tahap Menarik Kesimpulan

Berdasarkan hasil tes tulis, dimana subjek ZA dapat menarik kesimpulan dari awal sampai akhir penyelesaian dengan tepat dari sejumlah ide yang didapat dalam menyelesaikan soal. Adapun kutipan wawancara peneliti dengan subjek IPH adalah sebagai berikut:

P10 : Mengapa rencana penyelesaian tersebut kamu gunakan atau kamu lakukan? 
J10 : Karena soal nomor 1a mencari kerugian maka pembelian dikurangi penjualan dan soal nomor $1 b$ mencari kerugian maka penjulan dikurangi pembelian.

P11 : Dapatkah kamu memberikan kesimpulan dari soal nomor 1 (tentukan kerugian dan keuntungan)? J11 : Iya. Yang 1a kerugian yang dialami Pak Fikri adalah Rp. 15.000,00. 1b keuntungan yang diperoleh Pak Fikri jika menjual Rp. 10.000,00 mangga per-kg sama dengan Rp. 45.000,00.

Berdasarkan hasil wawancara, dapat diketahui bahwa subjek ZA langsung membuat hasil akhir dari pekerjaannya dan menuliskannya dengan benar dan jelas. Berdasarkan hasil tes tulis dan hasil wawancara, subjek ZA dapat membuat kesimpulan dengan benar. Hal ini dapat dilihat dari pekerjaan subjek ZA yang menuliskan kesimpulan akhir dengan benar. Setelah dikonfirmasi malalui tahap wawancara ternyata didapat fakta bahwa subjek ZA dapat membuat kesimpulan dari hasil akhir dengan benar. Sehingga dapat dikatakan bahwa subjek ZA telah melalui tahap menarik kesimpulan dengan baik.

\section{c. Subjek dengan gaya belajar kinestetik (MSAF)}

Hasil pekerjaan subjek MSAF pada soal nomor 1 yang digunakan untuk mengukur kemampuan berpikir logis dapat dilihat pada tabel dibawah ini:

Tabel 3. Hasil tes subjek MA nomor 1

\begin{tabular}{|c|c|}
\hline Penyelesaian & keterangan \\
\hline $\begin{array}{l}\text { 1. Diketahui: } 5 \text { kevanjang mangga dengan harga }=375.000,00 \\
\text { tiap kevanjang mangga bevisi : } 10 \mathrm{~kg} \\
\text { Biaya transpoutasi }=80.000,00 \\
\text { Harga } 1 \mathrm{~kg}=8.800,00 \\
\text { Ditanya: a.s keruglan yang dialami pak fikui } \\
\text { b.) Jika pak fikui menjual mangga dengan harga } \\
\text { Rp. } 10.000 / \mathrm{kg} \text {, berapa rupiah keuntungannya. }\end{array}$ & $\begin{array}{l}\text { KL } 1 \\
\text { PM } 1\end{array}$ \\
\hline $\begin{array}{l}\text { Jawab: } \\
\text { - } 5 \text { kevanjang bevisi : } 10 \times 5=50 \mathrm{~kg} \\
\text { - Havga } 50 \mathrm{~kg} \text { mangga: } 8.800 \times 50=440.000 \\
\text { - Harga jual } 5 \text { kevanjang mangga : } 440.000 \\
\text { - Harga beli }=375.000+80.000=455.000\end{array}$ & $\begin{array}{l}\text { KL } 2 \\
\text { PM } 2 \\
\text { PM } 3\end{array}$ \\
\hline $\begin{array}{l}\text { a.) Kevugian = 455.000-440.000 }=15.000,000 \\
\text { b.) Harga } 50 \text { mangga }=10.000 \times 50=500.000-375.000 \\
\text { keuntungan menjual mangga } 10.000,00=225.000,00\end{array}$ & $\begin{array}{l}\text { KL } 3 \\
\text { PM } 3\end{array}$ \\
\hline
\end{tabular}

-5 kevanjang bevisi : $10 \times 5=50 \mathrm{~kg}$

KL 4

- Harga $50 \mathrm{~kg}$ mangga: $8.800 \times 50=440.000$

PM 4

- Harga jual 5 keranjang mangga: 440.000

- Havga beli $=375.000+80.000=455.000$

a.) kevugian $=455.000-440.000=15.000,000$

b) Harga 50 mangga $=10.000 \times 50=500.000-375.000$

keuntungan menjual mangga $10.000,00=225.000, \infty$ 
Dari hasil pekerjaan subjek MSAF diatas, dapat dijelaskan bahwa:

1) KL 1: Tahap Klasifikasi

Subjek MSAF memahami masalah dari soal nomor 1, dimana subjek MSAF dapat menuliskan semua informasi yang diketahui dari soal dengan lengkap dan tepat dengan bahasa sendiri. Subjek MSAF juga dapat merumuskan pertanyaan yang diminta dari soal dengan benar dengan bahasa sendiri. Adapun kutipan wawancara peneliti dengan subjek MSAF adalah sebagai berikut:

P1 : Informasi apa yang ada dalam soal nomor 1 ?

J1 : $5 \mathrm{~kg}$ keranjang mangga dengan harga Rp. 375.000,00, tiap keranjang mangga berisi $10 \mathrm{~kg}$, biaya transportasi $\mathrm{Rp}$. 80.000,00, harga $1 \mathrm{~kg} R p .8 .800,00$.

P2 : Apa yang ditanyakan soal tersebut?

J2 : yang a kerugian yang dialami Pak Fikri, b jika Pak Fikri menjual mangga dengan harga Rp. $10.000,00 / \mathrm{kg}$, berapa rupiah keuntungannya.

Berdasarkan hasil wawancara diatas dapat diketahui bahwa subjek MSAF melalui tahap klasifikasi dengan baik. Subjek MSAF dapat menyebutkan semua informasi yang diketahui dan dapat merumuskan pertanyaan dari masalah soal nomor 1 dengan lengkap dan benar dengan bahasa sendiri.

Berdasarkan tes tulis dan hasil wawancara subjek MSAF dapat menuliskan semua informasi yang ada pada soal nomor 1 dan dapat merumuskan pertanyaan dari masalah dari soal nomor 1 dengan lengkap dan benar dengan bahasa sendiri. Setelah dikonfirmasi melalui tahap wawancara ternyata didapat suatu fakta bahwa subjek MSAF memang benar dapat menyebutkan semua informasi yang diketahui dari soal nomor 1 dengan lengkap dan benar. Subjek MSAF juga dapat merumuskan pertanyaan dari masalah soal nomor 1 dengan tepat sehingga dapat dikatakan bahwa subjek MSAF telah melalui tahap klasifikasi dengan baik.

2) KL 2: Tahap Menghubungkan

Dari penyelesaian yang dilakukan dimana subjek MSAF menuliskan semua informasi yang diketahui kemudian menghubungkan antara data yang diketahui dari soal dengan pengetahuan yang dimiliki mengubah dalam bentuk kalimat matematika (model matematika) secara jelas dan tepat dengan bahasa sendiri sehingga didapat suatu hasil yang kemudian digunakan untuk melakukan proses penyelesaian pada tahap berikutnya. Subjek MSAF telah merencanakan penyelesaian dan melakukan rencana penyelesaian, dapat memberikan keterangan pada bentuk matematika dari apa yang diketahui sebelumnya dan dapat menentukan rumus yang akan digunakan dengan benar dan tepat. Subjek MSAF juga mampu menyusun rencana penyelesaian dengan tepat. Adapun kutipan wawancara peneliti dengan subjek MSAF adalah sebagai berikut: P3 : Pengetahuan/konsep apa saja (yang sudah kamu pelajari) yang dibutuhkan untuk menyelesaikan masalah tersebut?

J3 : Mencari kerugian sama dengan harga beli dikurangi harga jual. Mencari keuntungan sama dengan harga jual dikurangi harga beli.

P4 : Apa yang dimaksud dari informasi yang telah kamu ketahui tadi?

J4 : Yang diketahui harga beli 5 keranjang mangga Rp. 375.000,00 dan biaya transportasi Rp. 80.000,00 maka Rp. 375.000,00 ditambah Rp. 80.000,00 sama dengan Rp. 455.000,00 adalah total harga beli. Harga jual adalah harga $50 \mathrm{~kg}$ mangga dikali Rp. 8.800,00 sama dengan Rp. 440.000,00.

P5 : Apakah semua informasi yang kamu sebutkan tadi kamu gunakan dalam menyelesaikan soal?

J5 : Iya. 
Berdasarkan hasil wawancara dapat diketahui bahwa subjek MSAF telah melakukan tahap menghubungkan dengan baik. Subjek MSAF mengemukakan apa yang dimaksud dari apa yang diketahui kemudian menghubungkannya dengan pengetahuan yang dimiliki dengan benar.

Berdasarkan hasil tes tulis dan hasil wawancara, subjek MSAF dapat melakukan tahap menghubungkan dengan benar. Setelah dikonfirmasi melalui tahap wawancara didapat suatu fakta bawha subjek MSAF memang benar dapat melakukan tahap menghubungkan dengan jelas dan benar dan menggunakan semua informasi yang diketahui pada soal serta dapat dapat menjelaskan alasan mengapa menggunakan semua informasi tersebut. Sehingga dapat dikatakan bahwa subjek MSAF telah melalui tahap menghubungkan dengan baik.

3) KL 3: Tahap Menghitung

Pada tahap menghitung, dimana subjek MSAF mampu melakukan operasi hitung dengan tepat pada soal nomor 1a dan mampu menyelesaikan dengan benar sesuai dengan langkahlangkah pada rencana penyelesaian. Namun pada soal nomor $1 \mathrm{~b}$ subjek MSAF tidak dapat melakukan operasi hitung dengan tepat (salah) pada langkah-langkah penyelesaian. Adapun kutipan wawancara peneliti dengan subjek MSAF adalah sebagai berikut:

P6 : Apakah rencana penyelesaian yang kamu pilih atau gunakan sudah runtut dan benar?

J6 : Iya.

P7 : Bagaimana cara kamu untuk bisa menjawab soal berdasarkan rencana penyelesaian yang kamu pilih?

J7 : Yang 1a mencari kerugian sama dengan harga beli Rp.455.000,00 dikurangi harga jual 5 keranjang mangga Rp. 440.000,00 sama dengan Rp. 15.000,00. Yang $1 \mathrm{~b}$ mencari keuntungan sama dengan harga jual $50 \mathrm{~kg}$ mangga sama dengan Rp. 10.000,00 dikali 50 sama dengan Rp. 500.000,00 dikurangi Rp. 375.000,00 sama dengan Rp. 225.000,00.

P8 : Apa kamu yakin dengan yang kamu kerjakan tadi?

J8 : Iya.

Berdasarkan hasil wawancara dapat dikatahui bahwa subjek MSAF telah melalui tahap menghitung pada soal nomor 1a saja pada soal 1b subjek MSAF tidak melalui tahap menghitung dengan baik karena pada hasil wawancara subjek MSAF tidak melakukan operasi hitung dengan tepat (salah) pada soal nomor $1 b$.

Berdasarkan hasil tes tulis dan hasil wawancara, subjek MSAF dapat melakukan tahap menghitung dengan benar sesuai langkah-langkah penyelesaian pada soal nomor 1a. Namun pada soal nomor $1 \mathrm{~b}$ subjek MSAF tidak dapat melalui tahap menghitung dengan baik karena terdapat kesalahan menghitung sehingga didapat suatu hasil yang kurang tepat. Setelah dikonfirmasi melalui tahap wawancara ternyata didapat suatu fakta bahwa subjek MSAF melakukan semua langkah-langkah penyelesaian yang benar pada soal nomor 1a dan melakukan kesalahan dalam proses penyelesaian pada soal nomor 1b. sehingga dapat dikatakan bahwa subjek MSAF tidak melalui tahap menghitung dengan baik.

4) KL 4: Tahap Menarik Kesimpulan

Dapat dilihat pada hasil tes tulis, dimana subjek MSAF tidak dapat menyimpulkan dari awal samapai akhir penyelesaian dari sejumlah ide yang didapatnya dalam menyelesaikan soal. Adapun kutipan wawancara peneliti dengan subjek MSAF adalah sebagai berikut:

P9 : Mengapa rencana penyelesaian tersebut kamu gunakan atau kamu lakukan?

J9 : Karena untuk mencari kerugian sama dengan harga beli dikurangi harga jual dan mencari keuntungan sama dengan harga jual dikurangi harga beli.

P10 : Dapatkah kamu memberikan kesimpulan dari soal nomor 1 (tentukan kerugian dan keuntungan)? 
J10 : yang a kerugian yang dialami adalah Rp. 15.000,00 dan keuntungan dari penjulan mangga dengan harga Rp. 10.000,00 adalah Rp. 225.000,00.

P11 : Mengapa kamu tidak menuliskan hasil kesimpulanmu pada lembar jawabanmu?

J11 : Hehehe iya tidak.

Berdasarkan hasil wawancara diatas, dapat diketahui bahwa subjek MSAF dapat memberikan kesimpulan dari awal sampai akhir penyelesaiannya dengan benar. Berdasarkan hasil tes tulis dan hasil wawancara, subjek MSAF tidak dapat membuat kesimpulan dari awal sampai akhir penyelesaian. Setelah dikonfirmasi melalui tahap wawancara ternyata didapat suatu fakta bahwa subjek MSAF dapat membuat kesimpulan dari hasil akhir dengan benar. Sehingga dapat dikatakan bahwa subjek MSAF tidak melalui tahap menarik kesimpulan dengan baik.

\section{Simpulan}

Dengan demikian dapat disimpulkan bahwa siswa pada subjek bergaya belajar visual (IPH) memiliki kemampuan berpikir logis pada pemecahan masalah yaitu pada tahap klasifikasi, tahap menghubungkan, tahap menghitung dan tahap menarik kesimpulan. Subjek bergaya belajar auditori (ZA) memiliki kemampuan berpikir logis pada pemecahan masalah yaitu pada tahap klasifikasi, tahap menghubungkan, tahap menghitung dan tahap menarik kesimpulan . Subjek bergaya belajar kinestetik (MSAF) memiliki kemampuan berpikir logis pada pemecahan masalah yaitu pada tahap klasifikasi, tahap menghubungkan dan tahap menarik kesimpulan.

\section{Daftar Rujukan}

Andriawan, B \& Budiarto, T. M. (2014). Identifikasi Kemampuan Berpikir Logis Dalam Pemecahan Masalah Matematika Pada Siswa Kelas VIII-1 SMP Negeri 2 Sidoarjo. Jurnal Ilmiah Pendidikan Matematika Volume 3 No. 2. Jurnal (Online).

Hidayat, Wahyu. 2014. Kemampuan Berpikir Logis Matematik.

http:// wahyu-hidayat.dosen.stkipsiliwangi.ac.id/2014/07/kemampuan-berpikirlogismatematik/. Diakses pada 08 April 2018, 19:08.

Rahmawati, N. K. dan Kurniasari, Ika. (2016). Profil Berpikir Logis Siswa dalam Memecahkan Masalah Matematika Menggunakan Test Of Plagets Logical Operations (TLO) ditinjau dari Kemampuan Matematika. Jurnal Ilmiah Pendidikan Matematika Volume 3 No. 5 Tahun 2016 ISSN: 12301-9085. Diakses pada 12 Maret 2018, 10:27.

Setiadi, D. (2017). Kemampuan Berpikir Logis Matematis Siswa Pada Pembelajaran Bangun Ruang dengan Menggunakan Strategi Problem Solving di Kelas IX SMPN 2 Mataraman. Skripsi (Online). Banjarmasin: Jurusan Pendidikan Matematika Fakultas Tarbiyah dan Keagamaan Institut Agama Islam Negeri Antasari Banjarmasin.

Sumarmo, Utari, dkk. (2012). Kemampuan dan Disposisi Berpikir Logis, Krisis, dan Kreatif Matematik (Eksperimen terhadap Siswa SMA Menggunakan Pembelajaran Berbasis Masalah dan Strategi Think-Talk-Write). Jurnal Pelajaran MIPA Volume 17 No. 1 April 2012 Halaman 17-33 ISSN: 1412-0917. Jurnal (Online).

Tarhadi. (2007). Penggunaan Tes Uraian Dibandingkan dengan Tes Pilihan Ganda Terstruktur dan Tes Pilihan Ganda Biasa. Article (Online). https:researchgate.net/publication/320843012. Diakses pada 16 Maret 2018, 17:51. 
Usdiyana, D, dkk. (2009). Meningkatkan Kemampuan Berpikir Logis Siswa SMP Melalui Pembelajaran Matematika Realistik. Jurnal Pengajaran MIPA Volume 13 No. 1 April 2009 ISSN: 1412-0917. Jurnal (Online). Diakses pada 12 Maret 2018, 10:35. 